\title{
Investigating the Influence of Website Design and its Determinants on the E-Business Success: An Empirical Analysis
}

\author{
Bader Methqal AIFawwaz \\ Department of Computer Information Systems \\ Al al-Bayt University, Jordan
}

\begin{abstract}
The success for a company performing E-commerce operations on the web is greatly depending on the quality of its website design and its determinants. The literature mentioned that the determinants of a quality website deigns are; Website Interface, Reliability, Customer Service/Customer Satisfaction, Security and Privacy and Etrust. The purpose is to see the effect of these website design and its determinants on electronic business performance. Electronic survey will be conducted in order to carry out this study and target audience will be online consumers or customers who shop online by navigating to different Ecommerce website, besides such managers and designers who have designed websites for different companies. Findings of the study show positive significant impact of determinants of a quality website deigns on electronic business performance in Jordan. The results show that the most important area was that towards website Design / interface issues. The results of this research gives an extensive overview to the managers and website designers who are working for or with different companies to make substantial decisions to increase the website quality, so to ultimately enhance the electronic business performance.
\end{abstract}

\section{Keyword:}

Electronic Business, Website, Website Design

\section{INTRODUCTION}

These days E-commerce business is on boom and more and more companies are trying to get competitive advantage by adapting different strategies on Internet. The growing adaption of Internet among companies and the Individuals is the enormous advancement in the field of information technology [1]. There is no doubt that web is a key channel for tourist destinations. A lot of tourist information available on web and users can access those information just by sitting in front of their computers [2]. Internet not only spread around the globe but it also changes the way organization performing work. From last few decades the rising trend on E-commerce is observed, which different organizations and people around the world is getting benefit of it by using this facility in certain ways. Companies have developed their online profiles so to access it by their customers spread all over the world. Further the companies which have already web profiles on Internet they have changed and improved their website according to the latest trends prevailing in the online world. This is important for the companies running operations on Internet is to improve their profits and to increase the sustainability in a seedy trending environment to meet their competitors. Many companies have developed their advance perfectly designed websites, and they are also moving towards alliances with software houses and licensing in order to get themselves into the online market. This phenomena is very trendy these days that e-commerce is not only supporting the offline business but it becomes main leading and independent venture for the companies. These days companies are using user historical databases which are associated with the ecommerce activities over the Internet. It involves certain web based tools such as Google Analytics [3].

There is no doubt that Internet can not only bring commerce facilities for the buyer and seller but it also ease out the purchasing process for the buyer and seller as well. In order to cater out the customer needs in this, online market companies have developed virtual image such as e-broachers, advertisements and website. Importance of website credibility, design and layout is not deniable. Studies have concluded that commercial medium such as website has its own importance and website cannot be left without giving it proper attention. Website is just like a corporate image and profile for a company and entire company is reflected in one website for its customers. It is important to study those factors for a website which enhanced the online trust towards its customers. Furthermore, it is also important to pay attention to develop such website designs which attract customers towards itself and as a result to make sales. A professional website should comprise the professional website lay out, design, reliability, easy to use, easy to navigate, help line or help desks for customers and the most important of all the security and trust on which customer rely and make purchases. As it has been observed that numbers of cybercriminal attacks are increased over the Internet, there are certain fraudulent activities going on stealing the information of customer and using it in wrong manner, therefore the security and confidentiality is also an important factor to cater out while developing a professional website for a company. One can say that a website is a novel way to communicate internally and externally, for correspondence, transfer of funds, transfer of data and more importantly buying and selling of goods and services over the web.

This study will assist Jordan companies by identifying and developing such factors that how they can enhance their reliability, credibility over the Internet. Further to build a framework regarding successful implementation of ecommerce operations on the Internet. Also this study will give a brief overview for the companies to develop and sustain a professional website in order to perform the successful electronic business on the Internet. As a developing economy of Jordan, it is important to conduct such researches in this country so that the companies having online operations in Jordan can meet the world's criteria of performing online business successfully. With the results of this study managers and decision makers can take certain decisions regarding improvement of their company's website.

\section{BACKGROUND OF THE STUDY}

In order to meet the criteria of scientific community for developing the results of this study, researcher has went 
through the relevant literature and published research papers with some of the published work in the context of Jordan to better understand the Jordan business environment.

The popularity and rapid development of Internet and web stores has increased the growth of Internet shopping, by providing a new channel for the online users to make purchases [4]. It is found that the effectiveness of certain trust-signaling features in the visual and social cue design dimensions are also significant for E-commerce decisions. The support for the positive effect of such website atmospheric cues is therefore important in order to enhance the online sales [5].

[6] stated that e-commerce implies certain consumer and legal challenges due to the increasing trend of e-commerce activities on the Internet. The primary focus of this research study was to emphasize on consumer and legal issues and challenges which are driven by the e-commerce and it found that there should be certain criteria set for those companies and even individual which are performing e-commerce activities on the Internet.

Findings of [7] stated that due to increasing number of online retailors on the web, the competition among the businesses is also increasing to gain the competitive advantage. Another study by [8] reveals that the importance of offline and physical shopping is reduced for many buyers just due to the fact that online buyers are increasing. Also in other words, we can say that due to the quality difference and professional services the consumers are more attracted towards the online shopping, as they can shop anything from the Internet without going outside.

A study conducted by [9] purely in the context of Jordan to find out the strategic position of Jordan industrial companies after the impact of e-commerce operations. The methodology of the study was quantitative, and sample size was 169 individuals working on the role of e-network in the four Jordan industrial companies. The electronic commerce measures were taken as customer attitude and behavior towards the buying, characteristics of the service or product offered by the company, commitment made by the management and some of the others. Further they also measure the strategic position of those industrial companies; the dimensions which were taken to measure the strategic performance of the company were return on investment (ROI), and some other major competitive edge characteristics. Results of the study indicated that there is positive significant relationship between dimension for e-commerce, dimensions

Independent Variables

\begin{tabular}{|ll|}
\hline & \\
& Website Quality \\
- & Website Interface \\
- & Reliability \\
- & Customer \\
& Service/Customer \\
& Satisfaction \\
- & Security and Privacy \\
& E-trust \\
\hline
\end{tabular}

of strategic performance of the company and industrial companies operating in Jordan.

A similar context of the study conducted by [10] gives important findings for decision makers and policy makers, especially those decision makers which are actively involved in the projects related to electronic government. Sample size was 31 companies which were selected from different sectors and industries such as service, manufacturing and even agriculture sector. The primary emphasize for this study was on two main factors; one is infrastructure for e-commerce and second is currently prevailing rules and regulations in the country as compared to the neighboring countries. It was found that there are no such rules and regulations prevail in the country right now in the context of e-commerce. Further it was found that Jordan has the easy and favorable amenities for the telecommunication services.

There is no doubt that website is just like a money making machine for those companies which are involved in ecommerce operations on Internet. A quantitative study performed by [11] with total sample size of 190 which includes $80 \%$ consumers who shop on Internet and $20 \%$ are the decision makers or managers which are working in such companies having electronic commerce operations. The quality factors of a high quality websites were measure by high quality designs, layouts, reliability, customer service, customer support, security \& privacy and with Electronic trust. A tourism analysis indicates that consumers are now using Internet to record their concerns and complaints regarding travel services which they have experienced [12].

The primary motive of the study was to investigate the quality factors of website and its design and their importance to the financial performance of the company. They found significant positive relationship between all website quality factors, domains for the electronic business website and e-business sales of the company. Further results indicated those website which are of high quality, high quality designs, layouts, reliable, customer oriented, security privacy and with E-trust have high turnover as compare to those websites which are not following these quality factors.

\section{THEORETICAL FRAMEWORK}

The Theoretical Framework of "Investigating the Influence of Website Design and its Determinants on the E-Business Success: An Empirical Analysis".

\section{Dependent Variables}

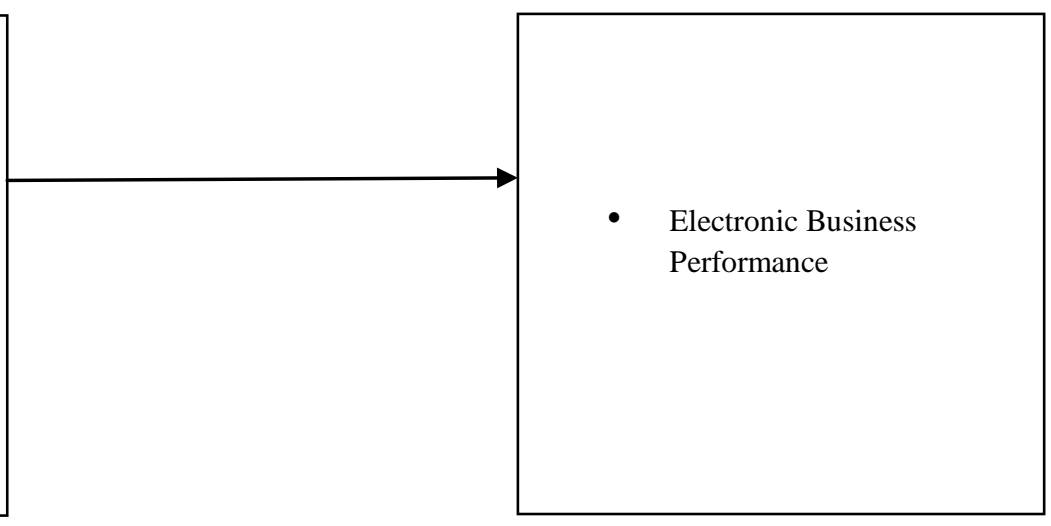

Figure (1): Theoretical Framework [13] 


\section{METHODOLOGY}

Methodology of the research is quantitative. It is the deductive study. Simple random sampling is used for gathering and collecting the data, because each sample has equal chances to be chosen. The study is basically targeting the Jordanian consumers who are shopping or using the products and services on Internet, besides such managers and designers who have designed websites for different companies. Questionnaire and Electronic Survey tool are used in order to conduct the studies effectively. The questionnaire was spread through e-mail and by hand in order to achieve the better results. This study is related to those users only, which are using online products and services. These products and services could be tangible and intangible as well. For instance; E-books, Garments Products, Gifts \& Accessories, Food, Online Banking, Purchasing Vehicles and purchasing anything through Electronic classifieds etc. The questionnaire was adopted from a similar context studies which has conducted by [13]. Samples were collected from several cities of Jordan by hand and e-mail. Sample size is 150 and it can be generalize to entire Jordan. After getting samples, data interpreted through SPSS software. The main purpose is to see the effect of these website design and its determinants on electronic business performance.

\section{RESULTS}

Table (1): Results Showing Reliability Statistics

\begin{tabular}{|c|c|c|}
\hline \multicolumn{2}{|c|}{ Reliability Test } \\
\hline Variables & Cronbach Alpha & N of Items \\
\hline Website Design / Interface & .71 & 05 \\
\hline Reliability & .72 & 16 \\
\hline $\begin{array}{c}\text { Customer Service/Customer } \\
\text { Satisfaction }\end{array}$ & .70 & 03 \\
\hline Security and Privacy & .73 & 05 \\
\hline E-trust & .75 & 03 \\
\hline
\end{tabular}

Table (2): Case Processing Summary

\begin{tabular}{|c|c|c|c|}
\hline & & $\mathbf{N}$ & $\%$ \\
\hline \multirow{3}{*}{ Cases } & Valid & 141 & 94.0 \\
\hline & Excludeda & 9 & 6.0 \\
\hline & Total & 150 & 100.0 \\
\hline
\end{tabular}

a. Listwise deletion based on all variables in theprocedure.

Table (3): Correlation Analysis

\begin{tabular}{|c|c|c|c|c|c|c|}
\hline Variables & $\begin{array}{c}\text { Electronic } \\
\text { Business } \\
\text { Performance }\end{array}$ & E-trust & $\begin{array}{c}\text { Security } \\
\text { and Privacy }\end{array}$ & Reliability & $\begin{array}{c}\text { Website } \\
\text { Design / } \\
\text { Interface }\end{array}$ & $\begin{array}{c}\text { Customer } \\
\text { Service/Customer } \\
\text { Satisfaction }\end{array}$ \\
\hline $\begin{array}{l}\text { Website Design / } \\
\text { Interface }\end{array}$ & .71 & .68 & .64 & .73 & 1 & .82 \\
\hline Reliability & .23 & .82 & .59 & 1 & .71 & .86 \\
\hline $\begin{array}{c}\text { Customer Service } \\
\text { /Customer Satisfaction }\end{array}$ & .85 & .68 & .62 & .69 & .65 & 1 \\
\hline Security and Privacy & .72 & .61 & 1 & .49 & .57 & .76 \\
\hline E-trust & .65 & 1 & .67 & .77 & .38 & .60 \\
\hline $\begin{array}{c}\text { Electronic Business } \\
\text { Performance }\end{array}$ & 1 & .78 & .71 & .69 & .73 & .75 \\
\hline
\end{tabular}


Table (4): Regression Analysis

\begin{tabular}{|c|c|c|c|c|c|c|c|}
\hline DV & IV & S.E & $\mathbf{R}$ & R square & Adj R Square & B & t-stats \\
\hline \multirow{5}{*}{$\begin{array}{c}\text { Electronic } \\
\text { Business } \\
\text { Performance }\end{array}$} & $\begin{array}{l}\text { Website Design / } \\
\text { Interface }\end{array}$ & \multirow{5}{*}{.3424} & \multirow{5}{*}{.538} & \multirow{5}{*}{.290} & \multirow{5}{*}{.195} & .296 & 2.119 \\
\hline & Reliability & & & & & .343 & 2.464 \\
\hline & $\begin{array}{c}\text { Customer } \\
\text { Service/Customer } \\
\text { Satisfaction }\end{array}$ & & & & & .438 & 3.026 \\
\hline & Security and Privacy & & & & & .574 & 4.09 \\
\hline & E-trust & & & & & .756 & 6.89 \\
\hline
\end{tabular}

\section{FINDINGS \& DISCUSSION}

The analysis of 32 question items which were comprised on various sections such as Website Interface, Reliability, Customer Service/Customer Satisfaction, Security and Privacy and E-trust suggest that these variables are positively depend of the electronic business performance in Jordan. The respondents were asked that to what extent quality website designs put impact on electronic business performance. Majority of the respondents said that by following these website designs practices, electronic business performance can increase which is a positive sign in the developing country like Jordan. The implementation of website design practices is positive for every business enterprise to follow the society's norms and values and gain the positive image towards itself.

On the basis of regression and correlation results dependency of independent variable towards dependent variable can be seen. The results in Table (4) indicated that almost all the values of T-stats are more than 2 which is a good indication. The Website Design / Interface t-value is 2.119 which is slightly greater than 2 , so based on this it is right to say that Website Design and Interface have strong positive relationship with the electronic performance of a business. Same in the case of Reliability practices, the t-value is 2.464 which is also greater than 2, so based on this empirical findings, it is found that Reliability have strong positive relationship with the electronic performance of a business. Similarly, the t-value of Customer Service/Customer Satisfaction is 3.026 which is also greater than 2 , so also based on the this empirical findings, it is right to say that Customer Service/Customer Satisfaction have strong positive relationship with the electronic performance of a business. Furthermore, the t-value of Security and Privacy practices is 4.09 which is also greater than 2 , so based on this empirical findings, it is found that Security and Privacy practices have strong positive relationship with the electronic performance of a business. Lastly, the t-value of E-trust is 6.89 which is greater than 2, so based on this empirical findings, it is right to say that E-trust have strong positive relationship with the electronic performance of a business.

\section{CONCLUSION}

The aim of this research stream was to empirically determine the impact of website design and its determinants on electronic business performance in Jordan. The empirical seating of the study is provided in the electronic business industry of Jordan. The main determinants of a quality website deigns are; Website Interface, Reliability, Customer Service/Customer Satisfaction, Security and Privacy and E- trust. The data was collected through questionnaire which was distributed among the online consumers or customers who shop online by navigating to different E-commerce website, besides such managers and designers who have designed websites for different companies. Data was analyzed by using SPSS 20 and regression correlation analysis was applied in order to estimate the results. Findings of the study show positive significant impact of determinants of a quality website deigns on electronic business performance in Jordan. The results show that the most important area was that towards Website Design / Interface issues.

Overall the empirical findings are according to the literature provided on this topic. The findings were in line with the finds of related studies. The study constructs an imperative input to the acquaintance of determinants of a quality website design in Jordan and it will stimulate advance exploration of website deigns in the Jordanian context, taking into explanation the confines of the study. This research stream will hopefully contribute to the recent literature of the quality website deigns practices and their effect on electronic business performance in Jordan.

\section{REFERENCES}

[1] Chircu, A. M., Davis, G. B., \& Kauffman, R. J. 2000. Trust, expertise, and e-commerce intermediary adoption. AMCIS 2000 Proceedings, 405

[2] Luna-Nevarez, C., \& Hyman, M. R. 2012. Common practices in destination website design. Journal of destination marketing \& management, Volume 1(1), pp. 94-106

[3] Carmona, C. J., Ramírez-Gallego, S., Torres, F., Bernal, E., del Jesus, M. J., \& García, S. 2012. Web usage mining to improve the design of an e-commerce website: OrOliveSur. com. Expert Systems with Applications, Volume 39(12), pp. 11243-11249.

[4] Kuo, H. M., \& Chen, C. W. 2011. Application of quality function deployment to improve the quality of Internet shopping website interface design. International Journal of Innovative Computing, Information and Control, Volume 7(1), pp. 253-268

[5] Karimov, F. P., Brengman, M., Van Hove, L., \& Van, L. 2011. The effect of website design dimensions on initial trust: a synthesis of the empirical literature. Journal of Electronic Commerce Research, Volume 12(4), pp. 272301. 
[6] Connolly, C. 1998. Electronic Commerce: Legal and Consumer Issues, Business Law Education Center.

[7] Lee, G.G. \& Lin, H.F. 2005. Customer perceptions of eservice quality in online shopping. International Journal of Retail and Distribution Management, Volume 33(2), pp. 161-176.

[8] Zhang, X. \& Tang, Y. 2006. Customer perceived eservice quality in online shopping. Master's Thesis, Lulea University of Technology. .

[9] Al-Khateeb, F. and Al-Husaini, F. 2001. The Impact of Electronic Commerce of The Strategic Position of Jordanian Industrial Firms, Dirasat Magazine, University of Jordan, Managerial Sciences, Volume 29, pp. 163181.
[10] Sahawneh, M. 2002. Ecommerce: The Jordanian Experience, Royal Scientific Society, Jordan.

[11] Younghwa Leea \& Kenneth A. Kozarb. 2006. Investigating the effect of website quality on e-business success: An analytic hierarchy process (AHP) approach. Decision Support Systems Volume 42 (3), pp. 13831401

[12] Mills, J. E., \& Law, R. 2013. Handbook of Consumer Behavior Tourism and the Internet. Routledge

[13] Bai, B., Law, R., \& Wen, I. 2008. The impact of website quality on customer satisfaction and purchase intentions: Evidence from Chinese online visitors. International Journal of Hospitality Management, Volume 27(3), pp. 391-402. 